\title{
Right versus left ventricular remodeling in heart failure due to chronic volume overload: pressure-volume and proteome analysis
}

Tereza Havlenova

Second Faculty of Medicine, Charles University, Prague

Petra Skaroupkova

Institute for Clinical and Experimental Medicine - IKEM

Matus Miklovic

Second Faculty of Medicine, Charles University, Prague

Matej Behounek

BIOCEV, Charles University

Martin Chmel

BIOCEV, Charles University

Dagmar Jarkovska

Faculty of Medicine in Pilsen, Charles University

Jitka Sviglerova

Faculty of Medicine in Pilsen, Charles University

Milan Stengl

Faculty of Medicine in Pilsen, Charles University

Michal Kolar

Institute of Molecular Genetics

Jiri Novotny

Institute of Molecular Genetics

Jan Benes

Institute for Clinical and Experimental Medicine - IKEM

Ludek Cervenka

Institute for Clinical and Experimental Medicine - IKEM

Jiri Petrak

BIOCEV, Charles University

Vojtech Melenovsky ( $\square$ vojtech.melenovsky@ikem.cz)

Institute for Clinical and Experimental Medicine - IKEM

\section{Research Article}

Keywords: biventricular response, volume overload, heart failure, aorto-caval fistula (ACF)/sham operation

Posted Date: April 8th, 2021

DOI: https://doi.org/10.21203/rs.3.rs-399870/v1

License: () (7) This work is licensed under a Creative Commons Attribution 4.0 International License. Read Full License 


\begin{abstract}
Mechanisms of right ventricular (RV) dysfunction in heart failure (HF) are poorly understood. RV response to volume overload (VO), a common contributing factor to HF, is rarely studied. The goal was to identify interventricular differences in response to chronic VO.
\end{abstract}

Rats underwent aorto-caval fistula (ACF)/sham operation to induce VO. After 24 weeks, RV and left ventricular (LV) functions, gene expression and proteomics were studied. ACF led to biventricular dilatation, systolic dysfunction and hypertrophy affecting relatively more RV. Increased RV afterload contributed to larger RV stroke work increment compared to LV. Both ACF ventricles displayed upregulation of genes of myocardial stress and metabolism. Most proteins reacted to VO in a similar direction in both ventricles, yet the expression changes were more pronounced in RV. The most upregulated were extracellular matrix (POSTN, NRAP, TGM2, CKAP4), cell adhesion (NCAM, NRAP, XIRP2) and cytoskeletal proteins (FHL1, CSRP3) and enzymes of carbohydrate (PKM) or norepinephrine (MAOA) metabolism. Downregulated were MYH6 and FAO enzymes.

Therefore, when exposed to identical VO, both ventricles display similar upregulation of stress and metabolic markers. RV reacts to ACF relatively more than LV due to concomitant pulmonary hypertension. No evidence supports RV chamber-specific regulation of protein expression in response to VO.

\title{
Introduction
}

Due to current scope of heart failure (HF) epidemics, exploration of new approaches to prevent or stabilize HF is a priority for research. One of important milestones of $\mathrm{HF}$ progression is the onset of right ventricular failure due to transition of initially left ventricular disease into biventricular $\mathrm{HF}$ with dismal prognosis ${ }^{1}$. Until recently, right ventricle (RV) received little attention and the mechanisms responsible for RV dysfunction are poorly understood ${ }^{2,3}$. RV differs in many aspects from the LV, having different embryonic origin, geometry, wall thickness and operating pressures ${ }^{2-6}$. Whether these differences translate into a "RV-specific" response to increased hemodynamic stress is unknown. Such interventricular differences may theoretically represent a target for chamberspecific therapies.

RV dysfunction can develop due to pressure overload resulting from pulmonary hypertension and this scenario is often investigated ${ }^{7,3}$. However, the response of RV to chronic volume overload (VO), a common contributing factor to HF, is studied much less ${ }^{8}$. The most frequent cause of VO of RV is severe tricuspid regurgitation that accompanies all forms of advanced $\mathrm{HF}^{9}$. Chronic VO of RV also occurs in patients with congenital heart disease ${ }^{10}$ or after implantation of left-ventricular assist device ${ }^{11,12}$. Therefore, chronic VO of RV is common, yet understudied condition.

Few studies examined molecular mechanisms of volume-induced RV dysfunction 8,10,13-17. It is unclear whether RV response fundamentally differ from LV response to excessive VO. Function of ventricles exposed to VO is influenced by altered loading and geometry, so only load-independent assessment by simultaneous invasive pressure-volume analysis can provide insight into chamber-specific responses to VO. Advantageous model to study interventricular differences in stress response is chronic infrarenal aorto-caval fistula (ACF), a condition that imposes identical VO both on the left and the right heart, leading to biventricular cardiac hypertrophy, dilatation, dysfunction and symptomatic heart failure ${ }^{18} 19$.

The goal of this study was to characterize the functional and molecular response of RV and LV to chronic VO and to identify hemodynamic factors that drive VO chamber remodeling using pressure-volume analysis, echocardiography, quantitative proteomics, and gene expression of selected genes previously implicated in development of RV failure ${ }^{14}$.

\section{Results}

\section{Cardiac structure and function in response to VO}

After 24 weeks of VO by ACF, we observed massive biventricular hypertrophy, relatively more pronounced on the right side (RV:+150\%, LV:+70\%, both $\mathrm{p}<$ 0.0001), increased atrial weight and increased lung weight due to congestion (Table 1). $70 \%$ of ACF animals showed clinical HF signs. ACF rats had similar tibial length as controls but were heavier due to presence of congestion. 
Table 1

Baseline characteristics and echocardiography.

\begin{tabular}{|c|c|c|c|c|}
\hline & Control & ACF & $\begin{array}{l}P \\
\text { (t-test) }\end{array}$ & $\begin{array}{l}\text { fold-change } \\
\text { ACF vs control }\end{array}$ \\
\hline Body weight (BW), g & $550 \pm 50$ & $610 \pm 70$ & 0.0035 & 1.1 \\
\hline Tibial length, mm & $43 \pm 1$ & $44 \pm 1$ & 0.3668 & 1.0 \\
\hline Heart weight/BW, g.kg-1 & $3.0 \pm 0.2$ & $5.9 \pm 0.8$ & $<0.0001$ & 2.0 \\
\hline LV weight/BW, g.kg ${ }^{-1}$ & $2.0 \pm 0.2$ & $3.4 \pm 0.5$ & $<0.0001$ & 1.7 \\
\hline RV weight/BW, g.kg ${ }^{-1}$ & $0.53 \pm 0.05$ & $1.3 \pm 0.2$ & $<0.0001$ & 2.5 \\
\hline Atrial weight/BW, g.kg-1 & $0.33 \pm 0.06$ & $1.0 \pm 0.2$ & $<0.0001$ & 3.0 \\
\hline Lung weight/BW, $\mathrm{g}^{\mathrm{kg}}{ }^{-1}$ & $3.5 \pm 0.4$ & $5 \pm 1$ & $<0.0001$ & 1.4 \\
\hline Heart failure score $(0-7)$ & $0.03 \pm 0.11$ & $1.6 \pm 1.5$ & $<0.0001$ & 53 \\
\hline \multicolumn{5}{|l|}{ Echocardiography: Left ventricle (LV) } \\
\hline LV end-diastolic dimension, $\mathrm{mm}$ & $6.7 \pm 0.6$ & $12 \pm 1$ & $<0.0001$ & 1.8 \\
\hline LV posterior wall thickness, $\mathrm{mm}$ & $2.6 \pm 0.3$ & $2.2 \pm 0.2$ & $<0.0001$ & 0.8 \\
\hline Relative wall thickness & $0.8 \pm 0.1$ & $0.33 \pm 0.05$ & $<0.0001$ & 0.4 \\
\hline LV fractional shortening, \% & $58 \pm 5$ & $38 \pm 6$ & $<0.0001$ & 0.7 \\
\hline Heart rate, $\min ^{-1}$ & $460 \pm 30$ & $370 \pm 40$ & $<0.0001$ & 0.8 \\
\hline Stroke volume, $\mathrm{ml}$ & $0.29 \pm 0.08$ & $1.5 \pm 0.3$ & $<0.0001$ & 5.2 \\
\hline Cardiac output, $\mathrm{ml} \cdot \mathrm{min}^{-1}$ & $130 \pm 30$ & $500 \pm 100$ & $<0.0001$ & 3.8 \\
\hline Mitral regurgitation grade $(1-4)$ & $0.3 \pm 0.5$ & $1.3 \pm 0.9$ & 0.0004 & 4.3 \\
\hline \multicolumn{5}{|l|}{ Echocardiography: Right ventricle (RV) } \\
\hline RVD1, mm & $3.6 \pm 0.3$ & $7 \pm 1$ & $<0.0001$ & 1.9 \\
\hline $\mathrm{RVD} 2, \mathrm{~mm}$ & $3.5 \pm 0.3$ & $7 \pm 1$ & $<0.0001$ & 2.0 \\
\hline $\mathrm{RVD} 3, \mathrm{~mm}$ & $9.7 \pm 0.7$ & $14 \pm 1$ & $<0.0001$ & 1.4 \\
\hline $\mathrm{RV}$ diastolic area, $\mathrm{mm}^{2}$ & $32 \pm 2$ & $90 \pm 20$ & $<0.0001$ & 2.8 \\
\hline RV FAC, \% & $49 \pm 4$ & $40 \pm 10$ & 0.0037 & 0.8 \\
\hline TAPSE, mm & $3.1 \pm 0.2$ & $3.9 \pm 0.7$ & $<0.0001$ & 1.3 \\
\hline RV global strain, \% & $-9 \pm 2$ & $-13 \pm 3$ & 0.0005 & 1.4 \\
\hline RV global strain rate, $\mathrm{s}^{-1}$ & $1.4 \pm 0.3$ & $2.0 \pm 0.4$ & $<0.0001$ & 1.4 \\
\hline Tricuspid regurgitation grade $(1-4)$ & $0.4 \pm 0.5$ & $1.3 \pm 0.8$ & 0.0012 & 3.3 \\
\hline
\end{tabular}

Echocardiography (Table 1, Fig. 1) confirmed LV chamber dilatation, wall thinning, eccentric remodeling, relative wall thinning and depressed global LV systolic function (LV fractional shortening: by -30\%) in ACF animals. Due to the systemic shunt, cardiac output was increased in ACF. Right ventricle showed enlargement and reduced global systolic function (RV FAC: by -20\%). Regional echocardiographic RV functional parameters (tricuspid annular plane systolic excursion-TAPSE, RV systolic strain) were influenced by marked ventricular remodeling/dilatation and overestimated RV systolic function.

Invasive hemodynamics and pressure-volume analysis (Table 2, Fig. 1) showed reduced systemic mean and diastolic blood pressure in ACF. End-diastolic filling pressures were increased in both ventricles, but more in the left ventricle. End-diastolic (and end-systolic) volumes were similarly increased in both

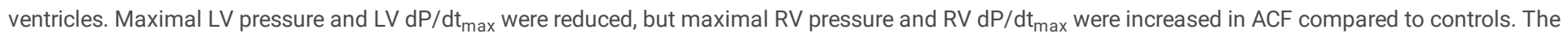
difference between maximal RV pressure and LV end-diastolic pressure that reflects transpulmonary pressure gradient (and precapillary component of pulmonary hypertension), was increased in ACF by $25 \%$ compared to controls. Ventricular stroke work was markedly increased in both ventricles, but the increase was relatively larger in the right ventricle (RV: 6.4-fold and LV: 3.5-fold, respectively). Load-independent measure of chamber contractility - preloadrecruitable stroke work (PRSW), was indeed significantly reduced both in ACF RV (by - 30\%, p = 0.0154) and LV (by - 60\%, $p=0.0021$ ), confirming depressed systolic chamber function. LV diastolic function was impaired (relaxation constant tau increased by $50 \%, \mathrm{p}<0.0001$; relaxation rate $\mathrm{dP} / \mathrm{dt}$ min decreased 2 -fold, $\mathrm{p}<0.0001$ ) but RV diastolic function was not influenced by ACF. 
Table 2

Hemodynamic data from pressure-volume analysis.

\begin{tabular}{|c|c|c|c|c|}
\hline & Control & ACF & $\begin{array}{l}P \\
\text { (t-test) }\end{array}$ & $\begin{array}{l}\text { fold-change } \\
\text { ACF vs control }\end{array}$ \\
\hline \multicolumn{5}{|l|}{ Systemic circulation } \\
\hline $\mathrm{SBP}, \mathrm{mmHg}$ & $140 \pm 30$ & $130 \pm 20$ & 0.1164 & 0.9 \\
\hline $\mathrm{DBP}, \mathrm{mmHg}$ & $110 \pm 30$ & $80 \pm 10$ & $<0.0001$ & 0.7 \\
\hline MBP, $\mathrm{mmHg}$ & $130 \pm 30$ & $110 \pm 20$ & 0.0024 & 0.8 \\
\hline $\mathrm{PP}, \mathrm{mmHg}$ & $29 \pm 6$ & $47 \pm 8$ & $<0.0001$ & 1.6 \\
\hline SVR, mmHg.min.ml-1 & $1 \pm 0.3$ & $0.21 \pm 0.05$ & $<0.0001$ & 0.2 \\
\hline \multicolumn{5}{|l|}{ Left Ventricle (LV) } \\
\hline LV EDP, mmHg & $6 \pm 2$ & $12 \pm 4$ & $<0.0001$ & 2.0 \\
\hline LV EDV, ml & $0.31 \pm 0.09$ & $2.0 \pm 0.5$ & $<0.0001$ & 6.5 \\
\hline LV mass/EDV, g.ml ${ }^{-1}$ & $3.8 \pm 0.9$ & $1.1 \pm 0.2$ & $<0.0001$ & 0.3 \\
\hline LV ESV, ml & $0.02 \pm 0.01$ & $0.5 \pm 0.3$ & $<0.0001$ & 25 \\
\hline LV max pressure, $\mathrm{mmHg}$ & $150 \pm 30$ & $120 \pm 20$ & $<0.0001$ & 0.8 \\
\hline LV max wall stress, mmHg.ml.g ${ }^{-1}$ & $40 \pm 10$ & $120 \pm 30$ & $<0.0001$ & 3.0 \\
\hline Stroke work, mmHg.ml & $20 \pm 6$ & $70 \pm 20$ & $<0.0001$ & 3.5 \\
\hline $\mathrm{dP} / \mathrm{dt}_{\text {max }}, \mathrm{mmHg} \cdot \mathrm{s}^{-1}$ & $10,000 \pm 4,000$ & $9,000 \pm 3,000$ & 0.1504 & 0.9 \\
\hline PRSW, mmHg & $70 \pm 40$ & $30 \pm 20$ & 0.0021 & 0.4 \\
\hline $\mathrm{dP} / \mathrm{dt}_{\min }, \mathrm{mmHg} \cdot \mathrm{s}^{-1}$ & $-11,000 \pm 3,000$ & $-5,000 \pm 2,000$ & $<0.0001$ & 0.5 \\
\hline Tau, ms & $11 \pm 2$ & $17 \pm 4$ & $<0.0001$ & 1.5 \\
\hline \multicolumn{5}{|l|}{ Right ventricle (RV) } \\
\hline $\mathrm{RV}$ EDP, mmHg & $4 \pm 1$ & $6 \pm 2$ & 0.0028 & 1.5 \\
\hline RV EDV, ml & $0.12 \pm 0.01$ & $0.7 \pm 0.3$ & $<0.0001$ & 5.8 \\
\hline $\mathrm{RV}$ mass/EDV, g.ml-1 & $2.4 \pm 0.3$ & $1.2 \pm 0.3$ & $<0.0001$ & 0.5 \\
\hline RV ESV, ml & $0.038 \pm 0.005$ & $0.3 \pm 0.2$ & $<0.0001$ & 7.9 \\
\hline $\mathrm{RV}$ max pressure, $\mathrm{mmHg}$ & $34 \pm 5$ & $46 \pm 6$ & $<0.0001$ & 1.4 \\
\hline RV max pressure - LVEDP gradient, $\mathrm{mmHg}$ & $28 \pm 6$ & $35 \pm 5$ & 0.0023 & 1.3 \\
\hline $\mathrm{RV}$ max wall stress, mmHg.ml.g ${ }^{-1}$ & $15 \pm 3$ & $36 \pm 9$ & $<0.0001$ & 2.4 \\
\hline Stroke work, mmHg.ml & $1.1 \pm 0.1$ & $7 \pm 3$ & $<0.0001$ & 6.4 \\
\hline $\mathrm{dP} / \mathrm{dt}_{\text {max }}, \mathrm{mmHg} \cdot \mathrm{s}^{-1}$ & $2,200 \pm 800$ & $2,900 \pm 800$ & 0.0265 & 1.3 \\
\hline PRSW, mmHg & $30 \pm 10$ & $20 \pm 10$ & 0.0154 & 0.7 \\
\hline $\mathrm{dP} / \mathrm{dt}_{\min }, \mathrm{mmHg} \cdot \mathrm{s}^{-1}$ & $-1,600 \pm 300$ & $-1,600 \pm 400$ & 0.9405 & 1.0 \\
\hline Tau, ms & $20 \pm 10$ & $20 \pm 10$ & 0.9954 & 1.0 \\
\hline
\end{tabular}

ACF had profound effect on duration of action potential $\left(\mathrm{APD}_{90}\right)$ that was similarly prolonged in both V0-exposed ventricles compared to controls (Fig. $\left.2 \mathrm{~A}, \mathrm{~B}\right)$. Trabecular contraction force had a trend towards RV-LV difference, without significant impact of ACF.

\section{Expression of target genes in response to VO}

Gene mRNA expression (qPCR) of selected genes (for list, see methods supplement) showed that ACF led to upregulation of myocardial stress genes (Fig. 3A): natriuretic peptide A (Nppa, more upregulated in LV than in RV) and increased myosin heavy chain isotype ratios (Myh7/6), mostly due to downregulated 
Myh6 gene. Monoamine oxidase-A (Maoa) and transglutaminase-2 (Tgm2), genes previously associated with ACF ${ }^{20}$, were similarly upregulated in RV and LV, $\operatorname{apelin}^{7}(A p / n)$ was similarly downregulated in both ACF ventricles, with no effect of VO on apelin receptor (Ap/nr) (Figure S1).

Metabolic genes showed a pattern consistent with HF-induced reprogramming (Fig. 3B). Increased ratio of gene expression changes of Hexokinase 1 ( $H k$ 1) to Medium chain Acyl CoA dehydrogenase (Acadm) reflected enhanced glycolysis over the fatty acid oxidation in both ventricles. Increased ratio of glucose transporters Glut1/G/ut4 was consistent with increased non-insulin dependent glucose uptake in ACF ventricles, more pronounced in RV. In both ventricles, VO had no effect on genes related to tissue hypoxia and angiogenesis (Vegf, Hif-1a), only Angiopoetin 2/Angiopoetin 1 ratio was significantly increased in both ACF ventricles, more in the LV. Expression of genes of cGMP-dependent signaling pathway (natriuretic peptide receptor 1 and 2: Npr1,2, soluble guanylate cyclase: Gucy1a3, cGMP-dependent protein kinase: Pkg, phosphodiesterase 5: Pde5a, Phosphodiesterase 9: Pde9a), was not consistently affected by V0 (Figure S1). Myocardial cGMP concentration was increased in ACF RV and LV (Figure S2), likely due to elevated levels of natriuretic peptides.

We correlated individual hemodynamic parameters with target gene expression changes in order to identify chamber-specific differences in response to Vo (Fig. 2C, Table S1). The variable with strongest correlation to myocardial stress response genes (Myh7/6 ratio) and metabolic genes (G/ut1/4 ratio) in both ventricles was end-diastolic volume and ventricular mass. For the same level of end-diastolic volume or mass increase, the gene expression in the RV was more pronounced (i.e. steeper regression slope) than in the LV. Such pattern, albeit weaker, was observed with other target genes. Directionality of gene expression-hemodynamics relations in RV corresponded to LV, with an important exemption of peak ventricular pressure (Fig. 2C). In the RV, higher maximal pressure linked with more pronounced gene expression, while in the LV, lower maximal pressure was associated with more remodeling. This indicates that ACF-induced changes in the right ventricle combine VO with simultaneous pressure overload, and lead to more pronounced gene expression changes, while the left ventricle in fact "pressure-unloaded" due to presence ACF combined with lower systemic pressures.

\section{Ventricular proteome response to VO}

Triplicate iTRAQ-based LC-MS/MS proteomic analysis of pooled samples of RVs and LVs of ACF and control animals identified over 3000 cardiac proteins. 1487 proteins were detected in all three replicates and provided quantitative expression data with adjusted p-value calculations. Only the proteins identified with at least 2 unique peptides (1372 proteins in total) were further considered (full list of identified proteins is provided as a supplementary dataset). 19 proteins were differentially expressed in both ACF ventricles ( $\geq 2$-fold change up or down with adjusted p-val $<0.05$ vs. controls), 25 additional proteins met the same differential expression criteria only in the RV (all also trending in LV) and 3 proteins were differentially expressed in the LV only (also trending in RV) (Table 3, Fig. 4). The differentially expressed proteins due to ACF were thus highly concordant between RV and LV without evidence of any protein expression changes specific for either ventricle. Yet, the magnitude of the ACF-induced expression changes was more pronounced in the RV (approximate ratio across all quantified proteins $1: 0.67$, Fig. 4) than in the LV. The individual list of the most differentially regulated proteins ( $>2$-fold change up or down compared to controls) is presented in Table 3 and is discussed below. Expression changes of selected proteins were confirmed by western blotting using specific antibodies (Fig. 5). 
Table 3

Differentially regulated proteins in RV vs LV due to volume overload.

\begin{tabular}{|c|c|c|c|c|c|c|c|c|c|c|c|}
\hline \multicolumn{8}{|c|}{ Proteins differentially expressed in both ventricles (2-fold, adj. P-value < 0.05 ) } & \multicolumn{2}{|c|}{ RV (ACF/CTRL) } & \multicolumn{2}{|c|}{ LV (ACF/CTRL) } \\
\hline Gene & Description & Function & Rel* & Accession & $\mathrm{C}[\%]$ & PSM & UP & Abundance & Adj. & Abundance & A \\
\hline & & & & & & & & Ratio: & P-Value: & Ratio: & $\mathbf{P}$ \\
\hline & & & & & & & & $(115) /(114)$ & $(115) /(114)$ & $(117) /(116)$ & $(1$ \\
\hline Postn & Periostin & $\begin{array}{l}\text { ECM, } \\
\text { myofibroblast } \\
\text { activation, } \\
\text { TGFbeta1 } \\
\text { pathway }\end{array}$ & 2 & D3ZAF5 & 35 & 60 & 21 & 7.54 & $<0.001$ & 3.43 & $<$ \\
\hline Maoa & $\begin{array}{l}\text { Amine oxidase [flavin- } \\
\text { containing] A }\end{array}$ & $\begin{array}{l}\text { degradation of } \\
\text { catecholamines, } \\
\text { ROS production }\end{array}$ & 2 & P21396 & 41 & 253 & 19 & 5.50 & $<0.001$ & 3.38 & $<$ \\
\hline Xirp2 & $\begin{array}{l}\text { Xin actin-binding repeat- } \\
\text { containing protein } 2\end{array}$ & $\begin{array}{l}\text { intercalated disc- } \\
\text { associated } \\
\text { protein, myofibril } \\
\text { assembly }\end{array}$ & 3 & F1LMC2 & 29 & 166 & 72 & 4.87 & $<0.001$ & 2.79 & $<$ \\
\hline Ncam1 & $\begin{array}{l}\text { Neural cell adhesion } \\
\text { molecule } 1\end{array}$ & $\begin{array}{l}\text { intercalated disc } \\
\text { protein, cell-cell } \\
\text { adhesion }\end{array}$ & 2 & F1LNY3 & 22 & 32 & 14 & 4.56 & 0.003 & 4.31 & 0 \\
\hline Tgm2 & $\begin{array}{l}\text { Tissue-type } \\
\text { transglutaminase }\end{array}$ & ECM cross-liking & 2 & Q9WVJ6 & 35 & 107 & 21 & 3.55 & $<0.001$ & 2.41 & $<$ \\
\hline Ighm & $\begin{array}{l}\text { Immunoglobulin heavy } \\
\text { constant mu }\end{array}$ & $\begin{array}{l}\text { immunoglobulin } \\
\text { component }\end{array}$ & 0 & A0A0G2K477 & 18 & 41 & 3 & 3.41 & 0.001 & 3.77 & 0 \\
\hline Nrap & $\begin{array}{l}\text { Nebulin-related- } \\
\text { anchoring protein }\end{array}$ & $\begin{array}{l}\text { intercalated disk, } \\
\text { actin-associated } \\
\text { protein, myofibril } \\
\text { assembly }\end{array}$ & 2 & D4A4K6 & 13 & 27 & 17 & 3.30 & 0.009 & 2.38 & 0 \\
\hline Kng1/2 & Kininogen 1 & $\begin{array}{l}\text { bradykinin, } \\
\text { coagulation }\end{array}$ & 1 & Q5PQU1 & 23 & 49 & 5 & 2.82 & $<0.001$ & 2.91 & $<$ \\
\hline Ckap4 & $\begin{array}{l}\text { Cytoskeleton-associated } \\
\text { protein } 4\end{array}$ & $\begin{array}{l}\text { ECM, } \\
\text { myofibroblast } \\
\text { activation }\end{array}$ & 2 & D3ZH41 & 56 & 28 & 12 & 2.60 & 0.001 & 2.43 & 0 \\
\hline Anxa5 & Annexin A5 & $\begin{array}{l}\text { Ca2 }+ \text { and } \\
\text { phospholipid } \\
\text { binding; } \\
\text { apoptosis, } \\
\text { sarcomere repair }\end{array}$ & 2 & P14668 & 69 & 215 & 19 & 2.53 & $<0.001$ & 2.10 & $<$ \\
\hline Prxl2a & Peroxiredoxin-like 2A & $\begin{array}{l}\text { ROS defense } \\
\text { protein }\end{array}$ & 1 & Q6AXX6 & 10 & 6 & 2 & 2.49 & 0.032 & 3.16 & 0 \\
\hline Fbn1 & Fibrillin 1 & ECM, microfibrils & 2 & G3V9M6 & 1 & 8 & 4 & 2.47 & 0.007 & 2.08 & 0 \\
\hline Hspb7 & $\begin{array}{l}\text { Heat shock } 27 \mathrm{kD} \text { protein } \\
\text { family, member } 7\end{array}$ & $\begin{array}{l}\text { sarcomere } \\
\text { proteostasis, } \\
\text { actin filament } \\
\text { assembly }\end{array}$ & 3 & B5DFG4 & 46 & 22 & 6 & 2.20 & 0.013 & 2.00 & 0 \\
\hline Fhl1 & $\begin{array}{l}\text { Four and a half LIM } \\
\text { domains } 1\end{array}$ & $\begin{array}{l}\text { sarcomere } \\
\text { stiffness } \\
\text { regulation, titin } \\
\text { binding }\end{array}$ & 3 & Q6P792 & 13 & 36 & 4 & 2.09 & 0.001 & 2.17 & 0 \\
\hline Coq10a & $\begin{array}{l}\text { Coenzyme Q-binding } \\
\text { protein COQ10 homolog } \\
\text { A }\end{array}$ & $\begin{array}{l}\text { mitochondrial; } \\
\text { postnatal } \\
\text { cardiomyocyte } \\
\text { growth }\end{array}$ & 1 & A0A0G2JYY6 & 19 & 14 & 4 & 0.47 & 0.000 & 0.50 & $<$ \\
\hline Decr1 & $\begin{array}{l}\text { 2,4-dienoyl-CoA } \\
\text { reductase }\end{array}$ & $\begin{array}{l}\text { mitochondrial; } \\
\text { beta oxidation of } \\
\text { unsaturated FA }\end{array}$ & 1 & Q64591 & 31 & 37 & 9 & 0.27 & $<0.001$ & 0.44 & $<$ \\
\hline Pi4ka & $\begin{array}{l}\text { Phosphatidylinositol 4- } \\
\text { kinase alpha }\end{array}$ & $\begin{array}{l}\text { first step of PI } 4,5 \\
\text { bisphosphate } \\
\text { synthesis }\end{array}$ & 0 & 008662 & 1 & 4 & 2 & 0.26 & 0.001 & 0.31 & 0 \\
\hline Tmod4 & Tropomodulin 4 & $\begin{array}{l}\text { thin filament } \\
\text { capping }\end{array}$ & 1 & D3ZSG3 & 19 & 18 & 4 & 0.25 & $<0.001$ & 0.49 & 0 \\
\hline
\end{tabular}

Rel* - relevance to known association with myocardium or hearth failure (HF): 0: no reports, 1: known to be in the heart, 2: associates with HF phenotype, pott modifies HF, 3: causally linked to HF, mutations are causal to HF/cardiomyopathy. C [\%] - percentual coverage; UP - number of unique peptides; PSM - num post translational modification. 


\begin{tabular}{|c|c|c|c|c|c|c|c|c|c|c|c|}
\hline \multicolumn{8}{|c|}{ Proteins differentially expressed in both ventricles ( 2 -fold, adj. P-value < 0.05 ) } & \multicolumn{2}{|c|}{ RV (ACF/CTRL) } & \multicolumn{2}{|c|}{ LV (ACF/CTRL) } \\
\hline Myh6 & Myosin-6 & $\begin{array}{l}\text { sarcomere, thick } \\
\text { filament } \\
\text { constituent }\end{array}$ & 3 & G3V885 & 67 & 5653 & 46 & 0.24 & $<0.001$ & 0.28 & $<$ \\
\hline \multicolumn{8}{|c|}{ Proteins differentially expressed in RV only (2-fold, adj. P-value < 0.05 ) } & \multicolumn{2}{|c|}{ RV (ACF/CTRL) } & \multicolumn{2}{|c|}{ LV (ACF/CTRL) } \\
\hline Synm & Synemin & $\begin{array}{l}\text { cytoskeletal; } \\
\text { intermediate } \\
\text { filament } \\
\text { component, } \\
\text { signaling }\end{array}$ & 3 & A0A096MK54 & 26 & 33 & 20 & 2.54 & 0.001 & 1.71 & 0 \\
\hline Mvp & Major vault protein & $\begin{array}{l}\text { ribonucleoprotein, } \\
\text { nuclear } \\
\text { membrane } \\
\text { transport }\end{array}$ & 0 & Q62667 & 45 & 100 & 26 & 2.38 & $<0.001$ & 1.93 & $<$ \\
\hline Hspb1 & $\begin{array}{l}\text { Heat shock } 27 \mathrm{kDa} \\
\text { protein } 1\end{array}$ & $\begin{array}{l}\text { chaperone, } \\
\text { mechanical } \\
\text { stress response }\end{array}$ & 2 & G3V913 & 88 & 111 & 13 & 2.16 & $<0.001$ & 1.69 & $<$ \\
\hline Map1a & $\begin{array}{l}\text { Microtubule-associated } \\
\text { protein } 1 \mathrm{~A}\end{array}$ & $\begin{array}{l}\text { cytoskeletal; } \\
\text { microtubules, } \\
\text { autophagy } \\
\text { regulation }\end{array}$ & 1 & G3V7U2 & 15 & 56 & 28 & 2.16 & $<0.001$ & 1.74 & $<$ \\
\hline Uap1 & $\begin{array}{l}\text { UDP-N- } \\
\text { acetylglucosamine } \\
\text { pyrophosphorylase } 1\end{array}$ & $\begin{array}{l}\text { GlcNAc } \\
\text { glycosylation }\end{array}$ & 0 & D3ZF39 & 15 & 14 & 6 & 2.15 & 0.028 & 2.27 & $\mathrm{~N}$ \\
\hline Pkm & Pyruvate kinase & $\begin{array}{l}\text { glycolysis } \\
\text { regulation }\end{array}$ & 2 & P11980 & 53 & 209 & 2 & 2.11 & 0.002 & 1.67 & 0 \\
\hline Xirp1 & $\begin{array}{l}\text { Xin actin-binding repeat } \\
\text { containing } 1\end{array}$ & $\begin{array}{l}\text { intercalated disc } \\
\text { associated } \\
\text { protein, myofibril } \\
\text { assembly }\end{array}$ & 3 & D4ABA9 & 24 & 39 & 18 & 2.10 & 0.003 & 1.79 & 0 \\
\hline Csrp3 & $\begin{array}{l}\text { Cysteine and glycine rich } \\
\text { protein } 3\end{array}$ & $\begin{array}{l}\text { gene for cardiac } \\
\text { LIM protein; } \\
\text { myogenesis, } \\
\text { stress-sensing }\end{array}$ & 3 & P50463 & 27 & 51 & 5 & 2.07 & 0.004 & 1.62 & 0 \\
\hline $\mathrm{Nt5c2}$ & $\begin{array}{l}\text { 5'-nucleotidase, } \\
\text { cytosolic II }\end{array}$ & $\begin{array}{l}\text { purine } \\
\text { metabolism, DNA } \\
\text { synthesis }\end{array}$ & 1 & D3ZMY7 & 10 & 17 & 4 & 2.07 & 0.003 & 1.50 & 0 \\
\hline Calu & Calumenin & $\begin{array}{l}\text { Ca binding } \\
\text { protein in ER/SR, } \\
\text { Ca cycling, ER } \\
\text { stress response }\end{array}$ & 1 & G3V6S3 & 57 & 47 & 12 & 2.07 & $<0.001$ & 1.68 & $<$ \\
\hline Ddah1 & $\begin{array}{l}N(G), N(G)- \\
\text { dimethylarginine } \\
\text { dimethylaminohydrolase } \\
1\end{array}$ & $\begin{array}{l}\text { degradation of } \\
\text { asymmetric } \\
\text { dimethylarginine; } \\
\text { NO signaling }\end{array}$ & 2 & 008557 & 34 & 41 & 8 & 2.06 & $<0.001$ & 1.60 & $<$ \\
\hline Vnn1 & Vanin 1 & $\begin{array}{l}\text { pantothenate } \\
\text { (vitamin B5) } \\
\text { metabolism }\end{array}$ & 0 & Q4KLZO & 23 & 30 & 7 & 2.05 & 0.004 & 1.79 & 0 \\
\hline Ckb & Creatine kinase B-type & $\begin{array}{l}\text { PCr/ATP } \\
\text { metabolism, fetal } \\
\text { isoform }\end{array}$ & 2 & P07335 & 57 & 209 & 14 & 2.01 & $<0.001$ & 1.52 & $<$ \\
\hline Myh10 & $\begin{array}{l}\text { Myosin, heavy } \\
\text { polypeptide } 10\end{array}$ & $\begin{array}{l}\text { non-muscle } \\
\text { myosin; } \\
\text { morphogenesis, } \\
\text { cytokinesis }\end{array}$ & 1 & G3V9Y1 & 10 & 41 & 4 & 2.00 & 0.009 & 1.95 & 0 \\
\hline Cbr4 & $\begin{array}{l}\text { Carbonyl reductase } \\
\text { family member } 4\end{array}$ & $\begin{array}{l}\text { xenobiotic } \\
\text { metabolism }\end{array}$ & 1 & Q7TS56 & 33 & 8 & 5 & 0.50 & 0.013 & 0.77 & $\mathrm{~N}$ \\
\hline Ckmt2 & $\begin{array}{l}\text { Creatine kinase S-type, } \\
\text { mitochondrial }\end{array}$ & $\begin{array}{l}\text { PCr/ATP } \\
\text { metabolism, } \\
\text { sarcomeric form }\end{array}$ & 2 & P09605 & 41 & 609 & 14 & 0.49 & $<0.001$ & 0.51 & $<$ \\
\hline Rmdn1 & $\begin{array}{l}\text { Regulator of microtubule } \\
\text { dynamics protein } 1\end{array}$ & $\begin{array}{l}\text { microtubules, } \\
\text { RNA splicing }\end{array}$ & 0 & Q4G069 & 33 & 47 & 9 & 0.47 & $<0.001$ & 0.67 & $<$ \\
\hline Col1a2 & $\begin{array}{l}\text { Collagen alpha-2(I) } \\
\text { chain }\end{array}$ & ECM, fibrosis & 1 & F1LS40 & 2 & 5 & 3 & 0.47 & 0.029 & 0.65 & $\mathrm{~N}$ \\
\hline
\end{tabular}

Rel* - relevance to known association with myocardium or hearth failure (HF): 0: no reports, 1 : known to be in the heart, 2: associates with HF phenotype, pot $\epsilon$ modifies HF, 3: causally linked to HF, mutations are causal to HF/cardiomyopathy. C [\%] - percentual coverage; UP - number of unique peptides; PSM - num post translational modification. 


\begin{tabular}{|c|c|c|c|c|c|c|c|c|c|c|c|}
\hline \multicolumn{8}{|c|}{ Proteins differentially expressed in both ventricles (2-fold, adj. P-value $<0.05$ ) } & \multicolumn{2}{|c|}{ RV (ACF/CTRL) } & \multicolumn{2}{|c|}{ LV (ACF/CTRL) } \\
\hline Gstz1 & $\begin{array}{l}\text { Maleylacetoacetate } \\
\text { isomerase }\end{array}$ & $\begin{array}{l}\text { xenobiotic and } \\
\text { glutathione } \\
\text { metabolism }\end{array}$ & 0 & P57113 & 53 & 41 & 8 & 0.47 & $<0.001$ & 0.85 & $\mathrm{~N}$ \\
\hline Acsf2 & $\begin{array}{l}\text { Medium-chain acyl-CoA } \\
\text { ligase ACSF2 }\end{array}$ & $\begin{array}{l}\text { fatty acid beta } \\
\text { oxidation }\end{array}$ & 0 & Q499N5 & 42 & 165 & 18 & 0.47 & $<0.001$ & 0.62 & 0 \\
\hline Coq8a & $\begin{array}{l}\text { Atypical kinase COQ8A, } \\
\text { mitochondrial }\end{array}$ & $\begin{array}{l}\text { coenzyme Q10 } \\
\text { biosynthesis }\end{array}$ & 0 & Q5BJQ0 & 39 & 103 & 16 & 0.46 & 0.002 & 0.53 & 0 \\
\hline Macrod1 & $\begin{array}{l}\text { ADP-ribose } \\
\text { glycohydrolase } \\
\text { MACROD1 }\end{array}$ & RNA processing & 1 & Q8K4G6 & 26 & 26 & 6 & 0.45 & $<0.001$ & 0.55 & $<$ \\
\hline Hadhb & $\begin{array}{l}\text { Trifunctional enzyme } \\
\text { subunit beta }\end{array}$ & $\begin{array}{l}\text { fatty acid beta } \\
\text { oxidation }\end{array}$ & 3 & Q60587 & 54 & 226 & 20 & 0.44 & $<0.001$ & 0.56 & $<$ \\
\hline Hadha & $\begin{array}{l}\text { Trifunctional enzyme } \\
\text { subunit alpha }\end{array}$ & $\begin{array}{l}\text { fatty acid beta } \\
\text { oxidation }\end{array}$ & 3 & Q64428 & 49 & 562 & 31 & 0.44 & $<0.001$ & 0.53 & $<$ \\
\hline Adssl1 & $\begin{array}{l}\text { Adenylosuccinate } \\
\text { synthetase isozyme } 1\end{array}$ & $\begin{array}{l}\text { purine } \\
\text { metabolism, AMP } \\
\text { synthesis }\end{array}$ & 1 & M0R629 & 47 & 76 & 15 & 0.37 & $<0.001$ & 0.57 & $<$ \\
\hline \multicolumn{7}{|c|}{ Proteins differentially expressed in LV only (2-fold, adj. P-value < 0.05 ) } & & \multicolumn{2}{|c|}{ RV (ACF/CTRL) } & \multicolumn{2}{|c|}{ LV (ACF/CTRL) } \\
\hline Aldh1a1 & Retinal dehydrogenase 1 & $\begin{array}{l}\text { retinoic acid } \\
\text { metabolism }\end{array}$ & 0 & P51647 & 41 & 54 & 15 & 1.72 & $<0.001$ & 2.08 & $<$ \\
\hline C9 & $\begin{array}{l}\text { Complement component } \\
\text { C9 }\end{array}$ & $\begin{array}{l}\text { innate immunity, } \\
\text { membrane attack } \\
\text { complex }\end{array}$ & 2 & Q62930 & 26 & 29 & 13 & 1.82 & $<0.001$ & 2.11 & $<$ \\
\hline Slc4a1 & $\begin{array}{l}\text { Band } 3 \text { anion transport } \\
\text { protein }\end{array}$ & $\begin{array}{l}\text { membrane } \\
\text { transport }\end{array}$ & 1 & P23562 & 19 & 32 & 14 & 1.66 & $<0.001$ & 3.69 & $<$ \\
\hline
\end{tabular}

Rel $^{*}$ - relevance to known association with myocardium or hearth failure (HF): 0: no reports, 1: known to be in the heart, 2: associates with HF phenotype, pot $\epsilon$ modifies HF, 3: causally linked to HF, mutations are causal to HF/cardiomyopathy. C [\%] - percentual coverage; UP - number of unique peptides; PSM - num post translational modification.

\section{Discussion}

The study describes biventricular changes in myocardial function and protein composition induced by chronic VO due to ACF. In response to ACF, both ventricles displayed eccentric hypertrophy, reduced contractility, prolonged duration of action potential, upregulation of genes associated with myocardial stress (Nppa, Myh7/6 ratio) and expression changes in substrate metabolic genes consistent with enhanced glycolysis and reduced fatty acid oxidation. By proteomic analysis, we identified several novel cardiac proteins differentially regulated by ACF with qualitatively concordant changes in both ventricles. The principal finding is that in response to identical surplus volume load, the pattern of proteome alterations is almost identical between ventricles, but the magnitude of changes is relatively more pronounced in the RV than in the LV. More pronounced changes on the right side can be explained by incremental RV pressure loading due to ACF-induced pulmonary vascular disease that combines with VO, while LV is exposed to lower systolic pressure due to a shunt in systemic circulation. Therefore, quantitative differences in protein expression between ventricles are explainable by hemodynamics, rather than by an existence of a "chamber-specific" regulation ${ }^{10}$. Study suggests that the primary approach how to preserve RV function and to prevent adverse RV remodeling in $\mathrm{HF}$ is to lower excessive hemodynamic loading.

\section{VO-induced changes in biventricular hemodynamics, structure and function}

Echocardiography showed eccentric remodeling, relative wall thinning, increased wall stress and depressed volumetric indices of function of both ventricles exposed to ACF. Indices of regional RV function (TAPSE, RV strain and strain rate) were paradoxically increased in ACF, likely due to confounding influence of chamber geometry, grossly changed by ACF. Therefore, TAPSE or strain deformation analysis overestimate RV contractility in volume overloaded ventricles. Limited utility of regional RV function indexes is also supported by low correlation of TAPSE, RV global strain and strain rate with gene expression of markers of myocardial remodeling (Table S1), in contrast to volumetric parameters.

Hemodynamic results are consistent with previous reports, although no study utilized pressure-volume analysis of both ventricles simultaneously in this model. While LV dP/dt $\mathrm{max}_{\text {ax }}$ showed a trend toward reduction in ACF compared to control ${ }^{19,21}, \mathrm{RV} \mathrm{dP} / \mathrm{dt}_{\max }$ was increased in $\mathrm{ACF}^{13,19}$, reflecting either afterloaddependence of this parameter or heterometric (Frank-Starling) adaptation to increased load. Load-independent measure of chamber contractility - preloadrecruitable stroke work (PRSW) was reduced in both ventricles, confirming indeed depressed systolic function ${ }^{15}$. Diastolic function (dP/dt ${ }_{\text {min }}{ }^{\text {and }}$ tau) was impaired in ACF LV, which might contribute to development of precapillary pulmonary hypertension component ${ }^{22}$.

Despite both ventricles handle the same increase in cardiac output in ACF, the increase in myocardial mass was relatively larger in the RV compared to LV (2.5 vs 1.7-fold, corresponding to LV/RV ratio of 0.7). Larger impact of ACF on RV compared to LV was noticed previously ${ }^{19,16,23}$. The explanation could be in a different stress response compensation, or due to difference in regulation of cardiac growth between ventricles ${ }^{24}$, or it can be explained hemodynamically. Our data support the latter mechanism. Pressure-volume data showed that ACF RV has to bear relatively higher increment of hemodynamic burden than LV. RV 
stroke work is increased 6.4-fold while LV stroke work is increased 3.5-fold in ACF compared to normal. Larger loading of the RV can be explained by pulmonary hypertension that adds to VO of the right heart, likely due to latent pulmonary vascular disease ${ }^{25}$ that is reflected by increased transpulmonary pressure gradient (RV peak pressure-LVEDP). Pulmonary vascular disease in ACF develops due to chronic elevation of pulmonary venous pressure ${ }^{22}$ and due to excessive pulmonary blood flow ${ }^{16,23,25}$.

Isolated ventricular trabeculae showed lower attained contraction of RV compared to LV, but no impact of ACF on developed force or force-frequency relationship. Some ${ }^{21,26}$ but not all 27,28 previous studies demonstrated reduced contractility of isolated cardiomyocytes ${ }^{21}$ or isolated papillary muscle preparations ${ }^{26,28}$ from rats with VO due to ACF. Further and more detailed analyses of RV and LV myofilament sensitivity are mandated. Both RV and LV from ACF group showed profound electrophysiological remodeling with almost doubling of action potential duration (APD) compared to controls. Prolongation of APD may be a compensatory mechanism how to maintain contraction strength in VO. APD prolongation is pro-arrhythmogenic and together with other mechanisms can contribute to increased risk of arrhythmic sudden death in volume-overloaded hearts ${ }^{29}$.

\section{V0-induced changes in biventricular mRNA gene expression}

VO led to upregulation of gene for natriuretic peptide A (Nppa) in both ventricles ${ }^{8,13,30}$. ACF-induced upregulation of ANP mRNA was massive and it was more pronounced in LV than in RV. In most HF animal models, including $\mathrm{ACF}^{31}$, as well as in humans with cardiac overload, the progression of cardiac hypertrophy into $\mathrm{HF}$ is associated with reduced expression of $M y h 6$ gene, coding a-myosin heavy chain, either absolutely or in relation to $M y h 7$, gene of $\beta$-myosin heavy chain ${ }^{13,31,32}$. Change of Nppa gene expression and $M y h 7 / 6$ ratio are therefore the most consistent molecular markers of HF and were upregulated in both VO-exposed ventricles. At a given surplus of mass, expression of Nppa or Myh7/6 were more pronounced in RV than in LV (Fig. 2C). Correlation analysis (Table S1) also showed that changes of $M y h 7 / 6$ and Nppa expression changes are linked with similar hemodynamic variables, and are likely co-regulated, in contrast to metabolic genes.

Volume overload led to change in genes of myocardial substrate metabolism and bioenergetics, such as increased G/ut1/4 ratio, indicative of enhanced insulin-independent glucose uptake, and increased $\mathrm{Hk} 1 / \mathrm{Mcad}$ ratio, indicative of enhanced glycolysis with reduced transcription of genes of fatty acid $\beta$ oxidation (Mcad). These changes were demonstrated in both ventricles. Similar pattern of metabolic gene transcription program was observed previously in pressure-overloaded ventricles, including $\mathrm{RV}^{33}$. In summary, metabolic response to stress resembles a reactivation of fetal gene expression program and is uniform in terms of chamber (RV vs LV) or overload etiology 33 .

We did not find altered expression of genes coding Vegfa and Hif1a in failing ventricles, but we observed increased ratio of Angpt2/Angpt1 mRNA (coding antiangiogenic angiopoietin-1 and angipoietin2), mostly in ACF LV, indicative of altered angiogenic signaling, similar to the response to myocardial infarction ${ }^{34}$. There were no consistent differences in genes of cGMP-dependent signaling pathway, speaking against relevance of this pathway in response to VO. Yet myocardial cGMP concentration was increased in ACF ventricles, probably reflecting stimulation of NP receptor-associated (particulate) guanylate cyclase by elevated natriuretic peptides.

VO in both ventricles led to downregulation of apelin, a small peptide with cardioprotective, inotropic and angiogenic properties that has contra-regulatory effects to renin-angiotensin system and acts via apelin receptor $\left(A p / n r^{35}\right.$. Downregulation of myocardial apelin was previously described in failing pressureoverloaded LV or RV7,35, but this is the first study that links apelin to volume overload-induced remodeling.

\section{VO-induced changes in biventricular proteome}

VO-induced changes in protein abundance were mostly similar between RV and LV. All differentially expressed proteins were either concordantly altered ( $\geq 2$ fold change FC) in both ventricles, or significantly altered only in one ventricle with concordant and/or not significant change of expression in the second ventricle. The data thus provide no support for chamber-specific protein expression patterns in response to similar hemodynamic stress, as proposed previously on basis of interventricular differences in physiology and embryonic origin ${ }^{10}$. Yet, protein deregulation was more pronounced in the right ventricle than in left with ratio of $1: 0.67$, i.e. regression line was tilted from the line of equivalence towards RV (Fig. 4D). Interestingly, this ratio is numerically close to the ratio of ventricular mass increments (RV/LV mass ratio 1:0.7). Proteome data also agree with hemodynamic data, as ACF led to more pronounced change in stroke work and myocardial mass in RV than in LV.

Most proteins emerged as differentially and correspondingly regulated in both ACF ventricles, compared to sham-operated ventricles, some of them for the first time associated with response to VO. The analysis of these proteins helps to understand VO-induced myocardial remodeling shared by both ventricles and they will be discussed by functional groups.

Proteins related to extracellular matrix (ECM): The most upregulated protein in ACF ventricles was periostin (POSTN) - a non-structural component of ECM, marker of myofibroblasts, cells necessary for cardiac adaptive healing and fibrosis ${ }^{36}$. Periostin assists in deposition of fibronectin-rich ECM and collagen crosslinking ${ }^{37}$, cardiomyocyte dedifferentiation ${ }^{38}$ and is extensively upregulated by TGF $\beta 1$, angiotensin II, infarction or hemodynamic overload, including $\mathrm{VO}^{39,40}$. VO-driven upregulation is almost twice in RV than in LV. Another TGF $\beta 1$-regulated protein upregulated in ACF hearts is cytoskeleton associated protein 4 (CKAP4), known to positively correlate with activated myofibroblast markers in both mouse and human cardiac tissue and to be negative modulator of fibroblast activation in injured heart ${ }^{41}$. We report again strong upregulation of tissue-type transglutaminase 2 (TGM2) in both ACF ventricles ${ }^{20}$, both on protein or mRNA level. TGM2 is responsible for crosslinking and stiffening of ECM and it was implicated in development of HF ${ }^{42}$. Another upregulated ECM protein is Fibrillin-1, a constituent of ECM microfibrils that is enhanced in ANGII-induced cardiac fibrosis ${ }^{43}$.

Sarcomeric, cytoskeletal, and cell-cell interaction proteins: Second large group of upregulated proteins in ACF were cytoskeletal proteins, sarcomeric proteins and proteins responsible for cell-cell interaction/force transduction. We report here an upregulation of two Xin actin-binding repeat-containing proteins XIRP1 
and XIRP2. These proteins with almost cardiac-specific expression are associated with intercalated disks and play a role in myofibril assembly and repair ${ }^{44}$. XIRP2 modulates the effects of ANG-II on cardiac hypertrophy, fibrosis and myosin isotype switch ${ }^{45}$, regulates voltage-gated K changes (KV1.5) ${ }^{46}$, and was found to be upregulated in RV by experimental volume-overload ${ }^{47}$. XIRPs may therefore represent potential markers of cardiac injury. Mutations of both XIRPs were associated with arrhythmic sudden cardiac death and prolonged action potential ${ }^{46}$, a feature present also in VO-ACF hearts (Fig. $3 \mathrm{~B}$ ).

From other sarcomeric proteins, we found downregulated gene for a-myosin heavy chain (MYH6), consistently with our targeted mRNA analysis and previous studies $^{32}$. Across species and types of overload, the downregulation of MYH6 gene is one of the hallmarks of HF ${ }^{48}$. ACF ventricles displayed also two-fold upregulation of non-muscle myosin 10 and downregulation of tropomodulin 4. Upregulated cytoskeletal signaling protein four and-a-half LIM domains 1 (FHL1) which binds to and regulates titin stiffness was already linked to VO-induced cardiac LV remodeling in rats ${ }^{30}$. Another sarcomeric stress-sensing element upregulated in ACF is cardiac cysteine and glycinerich protein 3 (CSRP3 aka MLP) ${ }^{49}$. Mutations in FHL $1^{50}$ and CSRP3 are known to cause cardiomyopathies. VO-ventricles showed an upregulation of Annexin-5, intracellular protein that participates in $\mathrm{Ca}^{2+}$ handling, apoptosis and sarcolemma repair and is upregulated in failing human myocardium ${ }^{51}$.

One of the most upregulated proteins in ACF ventricles was neural cell adhesion molecule 1 (NCAM1, 4.5-fold), a plasma membrane protein relevant for cardiomyocyte cell-cell interactions. NCAM1 is, similarly to identified ECM proteins, regulated by TGF $\beta^{52}$ and overexpressed in cardiomyocytes of other HF models and failing human hearts, proportionally to severity of $\mathrm{HF}^{53}$. Another VO-upregulated protein involved in cell-cell interactions is nebulin-related anchoring protein (NRAP), an actin-associated protein localized in intercalated disc, implicated in sarcomere assembly and force transduction. NRAP overexpression in the mouse leads to right ventricular cardiomyopathy ${ }^{54}$. Intermediate filament protein synemin (SYNM) that stabilizes intercalated disc and participates in protein kinase A signaling was also upregulated; its absence leads to severe cardiac abnormalities ${ }^{55}$. ACF ventricles showed an upregulation of microtubule-associated protein 1A (MAP1A), not previously associated with HF, and upregulation of major vault protein - a member of ribonucleoprotein complex relevant for nucleo-cytoplasmatic transport ${ }^{56}$.

Metabolic genes, ROS and chaperones: Proteomic analysis confirmed upregulation of glycolytic enzymes and downregulation of FA oxidation seen in targeted PCR analysis. Specifically, ACF ventricles showed upregulation of pyruvate kinase (PKM), the final enzyme of glycolysis. Upregulation of fetal isoform (PKM2) was previously observed in failing $\mathrm{RV}$ due to $\mathrm{PH}^{57}$. In parallel, we observed downregulation of $\alpha$ and $\beta$ subunits of trifunctional enzyme of $\beta$-oxidation of fatty acids (HADHA, HADHB), more pronounced in volume-overloaded RV than in LV, consistent with switch in myocardial metabolic preference typical to fetal or failing heart ${ }^{33,39}$. Downregulation of mitochondrial 2,4-dienoyl-CoA reductase, an enzyme of $\beta$-oxidation of unsaturated fatty acids, was also observed in both VO ventricles. We observed an upregulation of $B$ (fetal) isoform of creatine kinase (CK-B) that is typical for failing heart ${ }^{58}$ and a downregulation of its mitochondrial sarcomeric isoform (CKMT2), suggesting abnormalities in creatine shuttle and energy transfer.

Both ACF ventricles, but more RV, display strong upregulation of monoaminoxidase-A (MAOA), an enzyme that is responsible for degradation of catecholamines ${ }^{20}$. Upregulation of MAOA in ACF ventricles verifies our previous observation and is confirmed also on mRNA level (Fig. $3 \mathrm{~A}$ ) and by western blot (Fig. 5). MAOA might protect myocardium from untoward effects of increased norepinephrine spillover, but it is also a ROS-producing enzyme ${ }^{59}$. If MAO-A upregulation is adaptive or maladaptive in failing myocardium is therefore not known.

Both ACF ventricles showed upregulation of heat shock proteins: HSPB7 and HSPB1. HSPB7 is expressed almost exclusively in striated muscle and is critical for cardiac sarcomere assembly and proteostasis ${ }^{60}$. Genome-wide association study found that variation in HSPB7 locus is associated with reduced LV ejection fraction ${ }^{61}$.

Failing ACF ventricles (more RV than LV) showed upregulated dimethylarginine dimethylhydrolase1 (DDAH1), an enzyme that degrades asymmetric dimethyl arginine (ADMA), an endogenous inhibitor of nitric synthase. DDAH1-deficient rats have more severe PH and RV failure if exposed to monocrotaline ${ }^{62}$. In contrast, end-stage HF patients without $\mathrm{PH}$ have upregulated myocardial DDAH suggesting a contraregulatory response to putative ADMA elevation and ensuing NO deficit ${ }^{63}$.

The study has several limitations. To reduce variance, only male rats were studied. Cardiac tolerance to volume overload is worse in males than in females, i.e. changes were more pronounced ${ }^{64}$. Hemodynamics was tested only in resting state, without provocation maneuvers that could discern more subtle changes in cardiac function. Preload changing maneuvers (vena cava balloon inflation) were not performed due to technical reasons, i.e. we cannot report arterial or ventricular elastance values. Proteomic analysis did not detect some proteins that are known to be differentially regulated in HF and were even detected at mRNA level, such as collagens, apelin or apelin receptor. Such discrepancy can be explained by very low expression, insufficient solubility or low molecular weight of the protein with insufficient number of peptides generated by trypsin.

In conclusion, the study showed that ACF led to changes of molecular markers of heart failure, increased cardiac stress and altered substrate metabolism in both ventricles. RV reacted to ACF relatively more than LV, likely due to larger incremental stroke work due to pulmonary hypertension. Proteomic analysis identified high interventricular concordance of ACF-induced changes, indicating that the RV vs LV differences are explainable hemodynamically, rather than by a presence of "RV-specific" regulatory pathways. Reduction of PA pressure and RV load is therefore the primary instrument how to preserve RV function and adverse remodeling.

\section{Methods}

(for details, see supplementary information) 


\section{Heart failure model}

Eight-week male Sprague Dawley rats underwent needle ACF/sham operation as described previously ${ }^{18,65}$. After 24 weeks, RV and LV function (echocardiography, biventricular pressure-volume analysis, action potential duration), target gene expression (qPCR) and proteomics (LC-MS/MS) were studied. The investigation conformed to the NIH Guide for the care and use of laboratory animals (NIH Publication No. 85 - 23, 1996), Animal protection laws of the Czech Republic (311/1997) and was approved by the Ethic Committee of IKEM.

\section{Echocardiography and Hemodynamics}

Echocardiography was performed under general anesthesia with $10 \mathrm{MHz}$ transducer (Vivid System 7, GE, USA). RV fractional area change (FAC) was defined as difference of end-diastolic and end-systolic RV area, divided by end-diastolic area. RV volumes were calculated using monoplane ellipsoid approximation method $^{66}$. Subsequently, ventricular function was invasively assessed by $2 \mathrm{~F}$ Pressure-Volume micromanometer-tip catheters (Millar Instruments, Houston, TX, USA) simultaneously introduced into the LV via the right carotid artery and into the RV via the internal jugular vein. Data were analysed by LABCHART PRO software (ADInstruments, Bella Vista, NSW, Australia).

\section{Contractility and action potential duration measurements}

The papillary muscles were dissected from both ventricles. Contraction force and membrane potential was measured as described elsewhere ${ }^{67}$. Action potential duration (APD) was measured at $50 \%$ and $90 \%$ levels of repolarization (APD50, APD90).

\section{Gene expression analysis}

Samples were taken from RV and LV free wall and placed into RNA later. Total RNA was isolated and genomic DNA removed. RNA quantity and integrity were measured. The RNA was reverse transcribed and qPCR was done using RealTime ready Custom Panel 384-32 (Roche, p.n. 05582962 001). The analysis was performed on a LightCycler LC480 (Roche) according to manufacturer's protocol. Resulting data were analyzed by the $\Delta \mathrm{Cp}$ method using the R/Bioconductor statistical environment ${ }^{68-70}$.

\section{Proteomic analysis}

All chemicals were from Sigma-Aldrich, unless stated otherwise. Pooled pulverized myocardial samples were lysed, digested with trypsin using and labeled with four iTRAQ tags according to the manufacturer's instructions ${ }^{71}$. The samples were labeled as follows: tags as follows: 114 : right ventricle/control, 115 : right ventricle/ACF, 116: left ventricle/control, 117: left ventricle/ACF. To remove unbound tags and to pre-fractionate the peptides into four fractions SCX OPTITRAP $^{\text {TM }}$ Cartridge (Optimized Technologies, OR, USA) was used. Labeled peptide fractions were desalted and dried before LC-MS/MS analysis. $50 \mathrm{~cm}$ EASYSpray column (EASY-Spray column, $50 \mathrm{~cm}$ x $75 \mu \mathrm{m}$ ID, PepMap C18, $2 \mu \mathrm{m}$ particles, $100 \AA \AA$ pore size) with EASY-Spray ${ }^{\mathrm{Tm}}$ Source with PepMap100 Pre-column was used for on-line peptide fractionation. A linear gradient was applied for 240 minutes using Ultimate 3000 Nano LC (Dionex). Data were collected on Thermo Orbitrap Fusion ${ }^{\mathrm{TM}}$ in $\mathrm{MS}^{3}$ reporter ion quantification mode. The top 10 most intensive peaks from $\mathrm{MS}^{2}$ fragmentation were simultaneously selected and fragmented in HCD, MS ${ }^{3}$ masses were acquired in the Orbitrap. In total, three independent iTRAQ analyses using the same pooled myocardial samples were performed. The raw data from all three analyses (each comprising of 4 SCX fractions) were merged and analyzed in Proteome Discoverer 2.2. Data were searched against Rat SwissProt and TrEMBL databases using Sequest HT. FDR 0.01 limit for peptides and proteins was set. Quantitative data were normalized on total peptide amount. Unique and razor peptides were used for quantification.

\section{Western blot analysis}

Pulverized pooled heart samples were lysed, denatured and separated by SDS-PAGE. Proteins were transferred to PVDF membranes, which were than blocked and probed first with primary and then with HRP-conjugated secondary antibodies. The signal was detected using ECL detection system.

\section{Statistical analysis}

Data were assembled and statistically analyzed using JMP 14 software package (SAS, USA). Groups were compared using Student's t test and Pearson's correlation coefficient was used for assessment of correlation between continuous variables. Results are expressed as means \pm SD, if not stated otherwise. Pvalue less than 0.05 was considered significant.

\section{Declarations}

\section{Data availability}

All data generated or analyzed during this study are included in this published article (and its Supplementary Information files).

\section{Author contributions statement}

V.M., J.P. and T.H. wrote the manuscript. V.M., J.P., L.C., J.B, M.S. and M.K. designed the experiments. T.H., P.S., M.B., M.Ch., M.M., D.J., J.S. and J.N. carried out the lab work and/or analyzed the data. All authors commented and approved the final version of the manuscript.

\section{Acknowledgements}

This work has been supported by The Czech Agency for Healthcare Research (grants AZV 17-28784A, NV19-02-00130, NU20-02-00052), Czech National Infrastructure for Biological data (ELIXIR CZ, MEYS Grant No. LM2018131JN) and Charles University (Progres Q39 and Q26, SVV 260521, and UNCE/MED/016). 
Conflict of interest: There is no conflict of interest of any author of this manuscript.

Correspondence: Correspondence and requests for materials should be addressed to V.M.

Supplementary Information: Expanded Materials \& Methods section together with additional figures, tables and supplementary proteomic dataset are provided in the supplementary material.

\section{References}

1. Melenovsky, V. et al. Relationships between right ventricular function, body composition, and prognosis in advanced heart failure. J Am Coll Cardiol. 62 , 1660-1670 https://doi.org/10.1016/j.jacc.2013.06.046 (2013).

2. Voelkel, N. F. et al. Right ventricular function and failure: report of a National Heart, Lung, and Blood Institute working group on cellular and molecular mechanisms of right heart failure. Circulation. 114, 1883-1891 https://doi.org/10.1161/CIRCULATIONAHA.106.632208 (2006).

3. Haddad, F., Hunt, S. A., Rosenthal, D. N. \& Murphy, D. J. Right ventricular function in cardiovascular disease, part I: Anatomy, physiology, aging, and functional assessment of the right ventricle. Circulation. 117, 1436-1448 https://doi.org/10.1161/CIRCULATIONAHA.107.653576 (2008).

4. Amsallem, M., Mercier, O., Kobayashi, Y., Moneghetti, K. \& Haddad, F. Forgotten No More: A Focused Update on the Right Ventricle in Cardiovascular Disease. JACC. Heart failure. 6, 891-903 https://doi.org/10.1016/j.jchf.2018.05.022 (2018).

5. Haddad, F., Doyle, R., Murphy, D. J. \& Hunt, S. A. Right ventricular function in cardiovascular disease, part II: pathophysiology, clinical importance, and management of right ventricular failure. Circulation. 117, 1717-1731 https://doi.org/10.1161/CIRCULATIONAHA.107.653584 (2008).

6. Sanz, J. et al. Function, and Dysfunction of the Right Ventricle: JACC State-of-the-Art Review. J Am Coll Cardiol. 73, 1463-1482 https://doi.org/10.1016/j.jacc.2018.12.076 (2019).

7. Drake, J. I. et al. Molecular signature of a right heart failure program in chronic severe pulmonary hypertension. Am J Respir Cell Mol Biol. 45, 1239-1247 https://doi.org/10.1165/rcmb.2010-04120C (2011).

8. Bartelds, B. et al. Differential responses of the right ventricle to abnormal loading conditions in mice: pressure vs. volume load. Eur J Heart Fail. 13, 12751282 https://doi.org/10.1093/eurjhf/hfr134 (2011).

9. Wang, N. et al. Tricuspid regurgitation is associated with increased mortality independent of pulmonary pressures and right heart failure: a systematic review and meta-analysis. European heart journal. 40, 476-484 https://doi.org/10.1093/eurheartj/ehy641 (2019).

10. Reddy, S. \& Bernstein, D. Molecular Mechanisms of Right Ventricular Failure. Circulation. 132, 1734-1742 https://doi.org/10.1161/CIRCULATIONAHA.114.012975 (2015).

11. Houston, B. A., Shah, K. B., Mehra, M. R. \& Tedford, R. J. A new "twist" on right heart failure with left ventricular assist systems. J Heart Lung Transplant. 36, 701-707 https://doi.org/10.1016/j.healun.2017.03.014 (2017).

12. Lampert, B. C. \& Teuteberg, J. J. Right ventricular failure after left ventricular assist devices. J Heart Lung Transplant. 34, 1123-1130 https://doi.org/10.1016/j.healun.2015.06.015 (2015).

13. Bossers, G. P. L. et al. Volume load-induced right ventricular dysfunction in animal models: insights in a translational gap in congenital heart disease. Eur $J$ Heart Fail. 20, 808-812 https://doi.org/10.1002/ejhf.931 (2018).

14. Reddy, S. et al. Physiologic and molecular characterization of a murine model of right ventricular volume overload. American journal of physiology. Heart and circulatory physiology. 304, H1314-1327 https://doi.org/10.1152/ajpheart.00776.2012 (2013).

15. Borgdorff, M. A. et al. Distinct loading conditions reveal various patterns of right ventricular adaptation. American journal of physiology. Heart and circulatory physiology. 305, H354-364 https://doi.org/10.1152/ajpheart.00180.2013 (2013).

16. Modesti, P. A. et al. Different growth factor activation in the right and left ventricles in experimental volume overload. Hypertension. 43, 101-108 https://doi.org/10.1161/01.HYP.0000104720.76179.18 (2004).

17. Toischer, K. et al. Differential cardiac remodeling in preload versus afterload. Circulation. 122, 993-1003 https://doi.org/10.1161/CIRCULATIONAHA.110.943431 (2010).

18. Melenovsky, V. et al. The course of heart failure development and mortality in rats with volume overload due to aorto-caval fistula. Kidney \& blood pressure research. 35, 167-173 https://doi.org/10.1159/000331562 (2012).

19. Liu, Z., Hilbelink, D. R. \& Gerdes, A. M. Regional changes in hemodynamics and cardiac myocyte size in rats with aortocaval fistulas. 2. Long-term effects. Circulation research. 69, 59-65 https://doi.org/10.1161/01.res.69.1.59 (1991).

20. Petrak, J. et al. Proteomic and transcriptomic analysis of heart failure due to volume overload in a rat aorto-caval fistula model provides support for new potential therapeutic targets - monoamine oxidase A and transglutaminase 2. Proteome Sci. 9, 69 https://doi.org/10.1186/1477-5956-9-69 (2011).

21. Guggilam, A. et al. In vivo and in vitro cardiac responses to beta-adrenergic stimulation in volume-overload heart failure. Journal of molecular and cellular cardiology. 57, 47-58 https://doi.org/10.1016/j.yjmcc.2012.11.013 (2013).

22. Breitling, S., Ravindran, K., Goldenberg, N. M. \& Kuebler, W. M. The pathophysiology of pulmonary hypertension in left heart disease. Am J Physiol Lung Cell Mol Physiol. 309, L924-941 https://doi.org/10.1152/ajplung.00146.2015 (2015).

23. Rungatscher, A. et al. Chronic overcirculation-induced pulmonary arterial hypertension in aorto-caval shunt. Microvasc Res. 94, 73-79 https://doi.org/10.1016/j.mvr.2014.05.005 (2014). 
24. Borgdorff, M. A. et al. Sildenafil enhances systolic adaptation, but does not prevent diastolic dysfunction, in the pressure-loaded right ventricle. European journal of heart failure. 14, 1067-1074 https://doi.org/10.1093/eurjhf/hfs094 (2012).

25. Linardi, D. et al. Ventricular and pulmonary vascular remodeling induced by pulmonary overflow in a chronic model of pretricuspid shunt. $J$ Thorac Cardiovasc Surg. 148, 2609-2617 https://doi.org/10.1016/j.jtcvs.2014.04.044 (2014).

26. Gealekman, O., Abassi, Z., Rubinstein, I., Winaver, J. \& Binah, O. Role of myocardial inducible nitric oxide synthase in contractile dysfunction and betaadrenergic hyporesponsiveness in rats with experimental volume-overload heart failure. Circulation. 105, 236-243 https://doi.org/10.1161/hc0202.102015 (2002).

27. Ryan, T. D. et al. Left ventricular eccentric remodeling and matrix loss are mediated by bradykinin and precede cardiomyocyte elongation in rats with volume overload. Journal of the American College of Cardiology. 49, 811-821 https://doi.org/10.1016/j.jacc.2006.06.083 (2007).

28. Hisamatsu, Y. et al. Early changes in the functions of cardiac sarcoplasmic reticulum in volume-overloaded cardiac hypertrophy in rats. $J$ Mol Cell Cardiol. 29, 1097-1109 https://doi.org/10.1006/jmcc.1996.0327 (1997).

29. Sedmera, D. et al. Changes in Myocardial Composition and Conduction Properties in Rat Heart Failure Model Induced by Chronic Volume Overload. Frontiers in physiology. 7, 367 https://doi.org/10.3389/fphys.2016.00367 (2016).

30. Hutchinson, K. R., Saripalli, C., Chung, C. S. \& Granzier, H. Increased myocardial stiffness due to cardiac titin isoform switching in a mouse model of volume overload limits eccentric remodeling. J Mol Cell Cardiol. 79, 104-114 https://doi.org/10.1016/j.yjmcc.2014.10.020 (2015).

31. Freire, G., Ocampo, C., Ilbawi, N., Griffin, A. J. \& Gupta, M. Overt expression of AP-1 reduces alpha myosin heavy chain expression and contributes to heart failure from chronic volume overload. Journal of molecular and cellular cardiology. 43, 465-478 https://doi.org/10.1016/j.yjmcc.2007.07.046 (2007).

32. Wilson, K. et al. Effects of a myofilament calcium sensitizer on left ventricular systolic and diastolic function in rats with volume overload heart failure. American journal of physiology. Heart and circulatory physiology. 307, H1605-1617 https://doi.org/10.1152/ajpheart.00423.2014 (2014).

33. Koop, A. C. et al. Metabolic Remodeling in the Pressure-Loaded Right Ventricle: Shifts in Glucose and Fatty Acid Metabolism-A Systematic Review and Meta-Analysis. J Am Heart Assoc. 8, e012086 https://doi.org/10.1161/JAHA.119.012086 (2019).

34. Sandhu, R. et al. Reciprocal regulation of angiopoietin-1 and angiopoietin-2 following myocardial infarction in the rat. Cardiovascular research. 64, 115124 https://doi.org/10.1016/j.cardiores.2004.05.013 (2004).

35. Dalzell, J. R. et al. The Emerging Potential of the Apelin-APJ System in Heart Failure. Journal of cardiac failure. 21, 489-498 https://doi.org/10.1016/j.cardfail.2015.03.007 (2015).

36. Kanisicak, O. et al. Genetic lineage tracing defines myofibroblast origin and function in the injured heart. Nat Commun. 7, 12260 https://doi.org/10.1038/ncomms12260 (2016).

37. Landry, N. M., Cohen, S. \& Dixon, I. M. C. Periostin in cardiovascular disease and development: a tale of two distinct roles. Basic Res Cardiol. 113, 1 https://doi.org/10.1007/s00395-017-0659-5 (2018).

38. Bruns, D. R. et al. The right ventricular fibroblast secretome drives cardiomyocyte dedifferentiation. PLoS One. 14, e0220573 https://doi.org/10.1371/journal.pone.0220573 (2019).

39. Melenovsky, V. et al. Metabolic characterization of volume overload heart failure due to aorto-caval fistula in rats. Molecular and cellular biochemistry. 354, 83-96 https://doi.org/10.1007/s11010-011-0808-3 (2011).

40. Chen, Y. W. et al. Dynamic molecular and histopathological changes in the extracellular matrix and inflammation in the transition to heart failure in isolated volume overload. Am J Physiol Heart Circ Physiol. 300, H2251-2260 https://doi.org/10.1152/ajpheart.01104.2010 (2011).

41. Gladka, M. M. et al. Single-Cell Sequencing of the Healthy and Diseased Heart Reveals Cytoskeleton-Associated Protein 4 as a New Modulator of Fibroblasts Activation. Circulation. 138, 166-180 https://doi.org/10.1161/CIRCULATIONAHA.117.030742 (2018).

42. Shinde, A. V. et al. Tissue transglutaminase induction in the pressure-overloaded myocardium regulates matrix remodelling. Cardiovascular research. 113, 892-905 https://doi.org/10.1093/cvr/cvx053 (2017).

43. Bouzeghrane, F., Reinhardt, D. P., Reudelhuber, T. L. \& Thibault, G. Enhanced expression of fibrillin-1, a constituent of the myocardial extracellular matrix in fibrosis. Am J Physiol Heart Circ Physiol. 289, H982-991 https://doi.org/10.1152/ajpheart.00151.2005 (2005).

44. Leber, Y. et al. Filamin C is a highly dynamic protein associated with fast repair of myofibrillar microdamage. Hum Mol Genet. 25, 2776-2788 https://doi.org/10.1093/hmg/ddw135 (2016).

45. McCalmon, S. A. et al. Modulation of angiotensin II-mediated cardiac remodeling by the MEF2A target gene Xirp2. Circ Res. 106, 952-960 https://doi.org/10.1161/CIRCRESAHA.109.209007 (2010).

46. Huang, L. et al. Critical Roles of Xirp Proteins in Cardiac Conduction and Their Rare Variants Identified in Sudden Unexplained Nocturnal Death Syndrome and Brugada Syndrome in Chinese Han Population. J Am Heart Assoc. 7, https://doi.org/10.1161/JAHA.117.006320 (2018).

47. Charron, S. et al. Identification of Region-Specific Myocardial Gene Expression Patterns in a Chronic Swine Model of Repaired Tetralogy of Fallot. PLoS One. 10, e0134146 https://doi.org/10.1371/journal.pone.0134146 (2015).

48. Lowes, B. D. et al. Changes in gene expression in the intact human heart. Downregulation of alpha-myosin heavy chain in hypertrophied, failing ventricular myocardium. J Clin Invest. 100, 2315-2324 https://doi.org/10.1172/JCl119770 (1997).

49. Buyandelger, B. et al. MLP (muscle LIM protein) as a stress sensor in the heart. Pflugers Archiv: European journal of physiology. 462, 135-142 https://doi.org/10.1007/s00424-011-0961-2 (2011).

50. Hartmannova, H. et al. Isolated X-linked hypertrophic cardiomyopathy caused by a novel mutation of the four-and-a-half LIM domain 1 gene. Circulation. Cardiovascular genetics. 6, 543-551 https://doi.org/10.1161/CIRCGENETICS.113.000245 (2013).

Page $13 / 19$ 
51. Camors, E., Monceau, V. \& Charlemagne, D. Annexins and Ca2 + handling in the heart. Cardiovasc Res. 65, 793-802 https://doi.org/10.1016/j.cardiores.2004.11.010 (2005).

52. Ackermann, M. A. et al. TGF-beta1 affects cell-cell adhesion in the heart in an NCAM1-dependent mechanism. J Mol Cell Cardiol. 112, 49-57 https://doi.org/10.1016/j.yjmcc.2017.08.015 (2017).

53. Nagao, K. et al. Myocardial expression level of neural cell adhesion molecule correlates with reduced left ventricular function in human cardiomyopathy. Circulation. Heart failure. 7, 351-358 https://doi.org/10.1161/CIRCHEARTFAILURE.113.000939 (2014).

54. Lu, S. et al. Cardiac-specific NRAP overexpression causes right ventricular dysfunction in mice. Experimental cell research. 317, 1226-1237 https://doi.org/10.1016/j.yexcr.2011.01.020 (2011).

55. Garcia-Pelagio, K. P. et al. Absence of synemin in mice causes structural and functional abnormalities in heart. Journal of molecular and cellular cardiology. 114, 354-363 https://doi.org/10.1016/j.yjmcc.2017.12.005 (2018).

56. Shults, N. V., Das, D. \& Suzuki, Y. J. Major vault protein in cardiac and smooth muscle. Receptors \& clinical investigation 3(2016).

57. Xiong, P. Y. et al. Biventricular Increases in Mitochondrial Fission Mediator (MiD51) and Proglycolytic Pyruvate Kinase (PKM2) Isoform in Experimental Group 2 Pulmonary Hypertension-Novel Mitochondrial Abnormalities. Frontiers in cardiovascular medicine. 5, 195 https://doi.org/10.3389/fcrm.2018.00195 (2018).

58. Shen, W. et al. The fall in creatine levels and creatine kinase isozyme changes in the failing heart are reversible: complex post-transcriptional regulation of the components of the CK system. Journal of molecular and cellular cardiology. 39, 537-544 https://doi.org/10.1016/j.yjmcc.2005.05.003 (2005).

59. Kaludercic, N., Mialet-Perez, J., Paolocci, N., Parini, A. \& Di Lisa, F. Monoamine oxidases as sources of oxidants in the heart. J Mol Cell Cardiol. 73, 34-42 https://doi.org/10.1016/j.yjmcc.2013.12.032 (2014).

60. Mercer, E. J., Lin, Y. F., Cohen-Gould, L. \& Evans, T. Hspb7 is a cardioprotective chaperone facilitating sarcomeric proteostasis. Dev Biol. 435, 41-55 https://doi.org/10.1016/j.ydbio.2018.01.005 (2018).

61. Aung, N. et al. Genome-Wide Analysis of Left Ventricular Image-Derived Phenotypes Identifies Fourteen Loci Associated With Cardiac Morphogenesis and Heart Failure Development. Circulation. 140, 1318-1330 https://doi.org/10.1161/CIRCULATIONAHA.119.041161 (2019).

62. Wang, D. et al. Dimethylarginine dimethylaminohydrolase 1 deficiency aggravates monocrotaline-induced pulmonary oxidative stress, pulmonary arterial hypertension and right heart failure in rats. International journal of cardiology. 295, 14-20 https://doi.org/10.1016/j.ijcard.2019.07.078 (2019).

63. Shao, Z. et al. Pulmonary hypertension associated with advanced systolic heart failure: dysregulated arginine metabolism and importance of compensatory dimethylarginine dimethylaminohydrolase-1. Journal of the American College of Cardiology. 59, 1150-1158 https://doi.org/10.1016/j.jacc.2011.12.022 (2012).

64. El Hajj, M. C., Ninh, V. K., Hajj, E., Bradley, E. C., Gardner, J. D. \& J. M. \& Estrogen receptor antagonism exacerbates cardiac structural and functional remodeling in female rats. American journal of physiology. Heart and circulatory physiology. 312, $\mathrm{H} 98-\mathrm{H} 105$ https://doi.org/10.1152/ajpheart.00348.2016 (2017).

65. Cervenka, L. et al. Inhibition of soluble epoxide hydrolase counteracts the development of renal dysfunction and progression of congestive heart failure in Ren-2 transgenic hypertensive rats with aorto-caval fistula. Clinical and experimental pharmacology \& physiology. 42, 795-807 https://doi.org/10.1111/1440-1681.12419 (2015).

66. Lange, P. E. et al. Value of image enhancement and injection of contrast medium for right ventricular volume determination by two-dimensional echocardiography in congenital heart disease. Am J Cardiol. 55, 152-157 https://doi.org/10.1016/0002-9149(85)90318-2 (1985).

67. Sviglerova, J. et al. Cardiac remodeling in rats with renal failure shows interventricular differences. Exp Biol Med (Maywood). 237, 1056-1067 https://doi.org/10.1258/ebm.2012.012045 (2012).

68. Livak, K. J. \& Schmittgen, T. D. Analysis of relative gene expression data using real-time quantitative PCR and the 2(-Delta Delta C(T)) Method. Methods. 25, 402-408 https://doi.org/10.1006/meth.2001.1262 (2001).

69. Huber, W. et al. Orchestrating high-throughput genomic analysis with Bioconductor. Nat Methods. 12, 115-121 https://doi.org/10.1038/nmeth.3252 (2015).

70. McCall, M. N., McMurray, H. R., Land, H. \& Almudevar, A. On non-detects in qPCR data. Bioinformatics. 30, 2310-2316 https://doi.org/10.1093/bioinformatics/btu239 (2014).

71. Wisniewski, J. R., Zougman, A., Nagaraj, N. \& Mann, M. Universal sample preparation method for proteome analysis. Nat Methods. 6, 359-362 https://doi.org/10.1038/nmeth.1322 (2009).

\section{Figures}



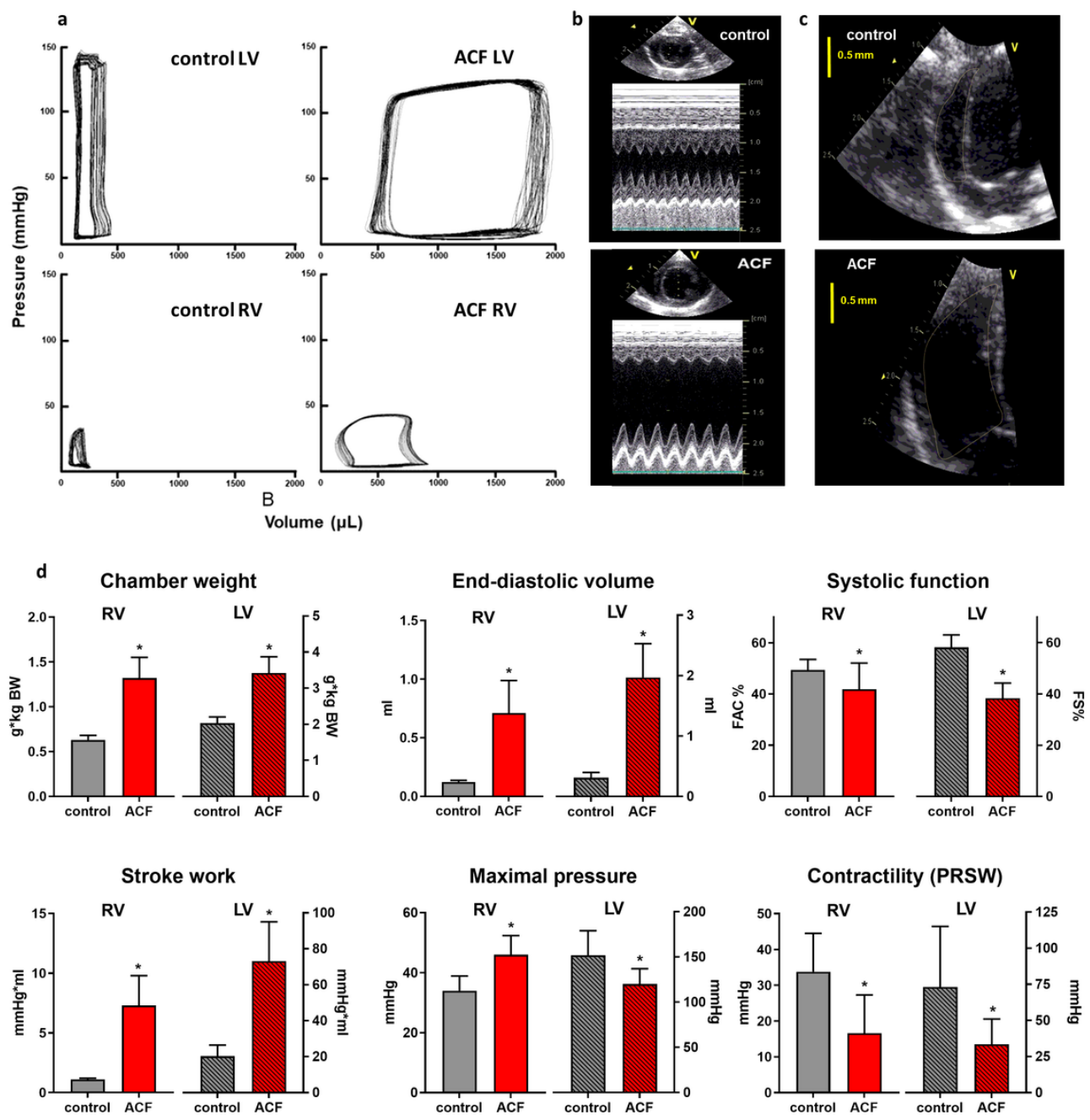

Figure 1

Volume overload-induced cardiac remodeling of right (RV) and left (LV) ventricle. a) Representative example of pressure-volume (PV) loops in HF and controls.

b) Echocardiographic parasternal short axis view of LV in M-mode, c) 4-chamber view of RV in controls and ACF. d) Hemodynamic parameters and PV analysis results in $\operatorname{ACF}(\mathrm{N}=26)$ and controls $(\mathrm{N}=16)$. Data are presented as means $\pm S D$. ${ }^{2} \mathrm{p}<0.05$ vs controls. 


\section{Action potential and contraction force}

a

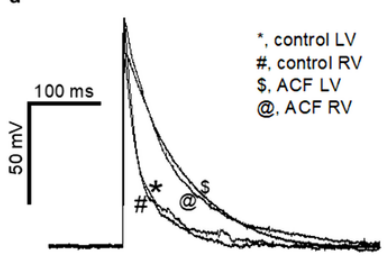

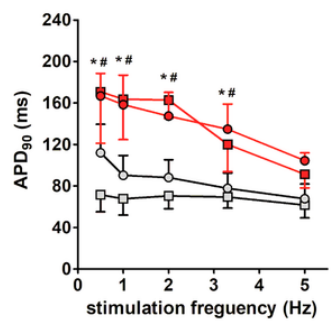

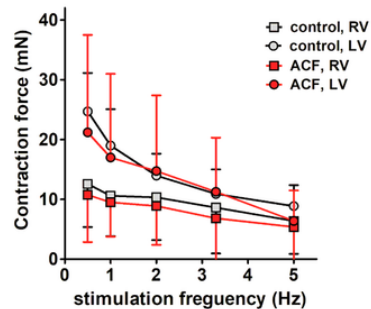

c

Volume-induced remodelling of RV vs LV
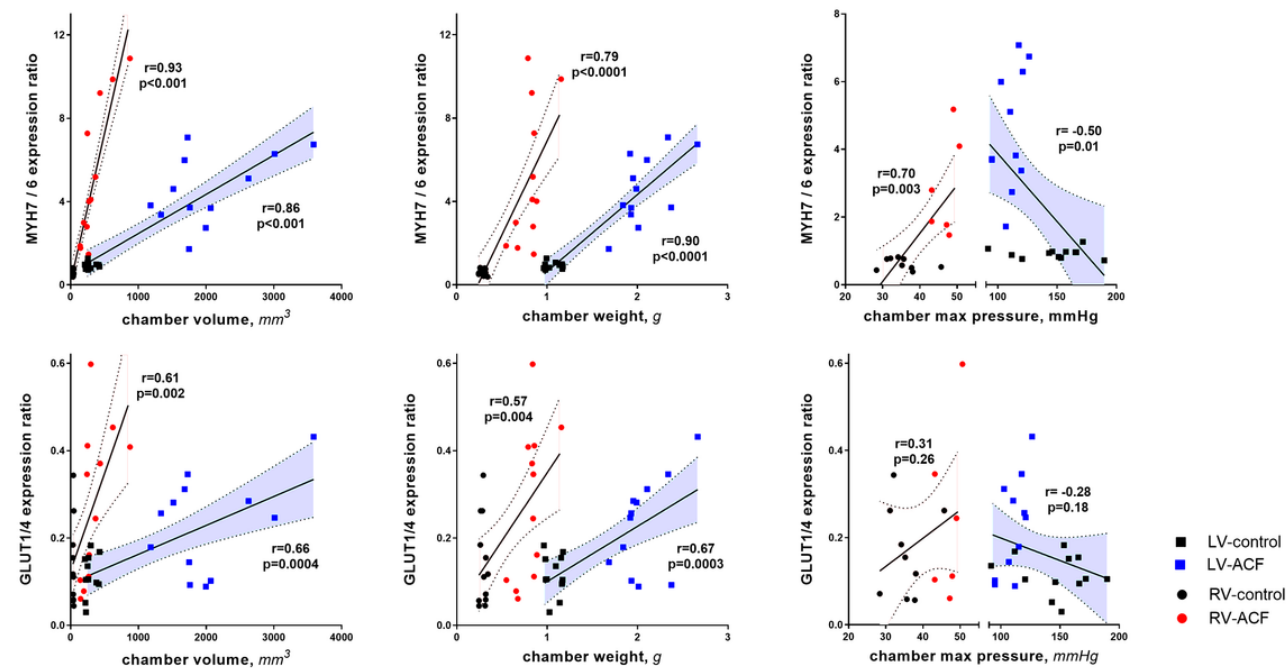

\section{Figure 2}

Biventricular differences in contraction force, action potential duration and mRNA expression regulation in volume overload from aorto-caval fistula (ACF). a) Example of action potential recording from isolated papillary muscle. b left) Action potential duration at 90\% repolarization (APD90) in RV and LV papillary muscles in controls and in ACF rats. Measurements at stimulation frequencies of 0.5, 1, 2, 3.3 and $5 \mathrm{~Hz}$. *, p<0.05, RV control vs. RV ACF; \#, p<0.05, LV control vs. LV ACF (3-way ANOVA). b right) Maximal contraction force in RV and LV papillary muscles in control and ACF rats. c) Relation of hypertrophy determinants to gene mRNA expression patterns in RV and LV. Note discordant relations between gene expression and ventricular pressures; concordant but steeper relation of RV compared to LV. 
myocardial stress

a
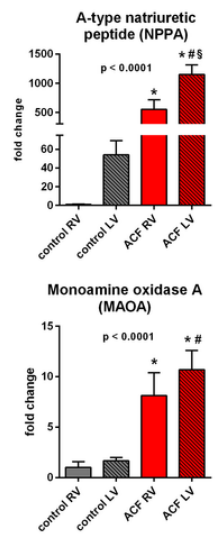

b
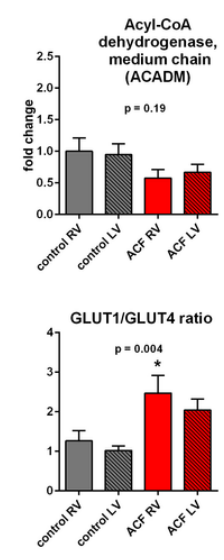

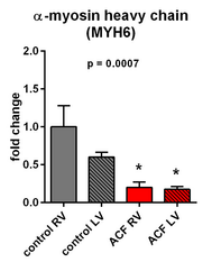

Transglutaminase 2
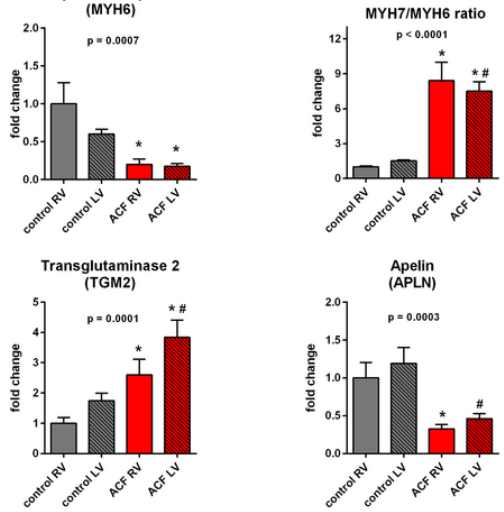

Apelin
(APLN)

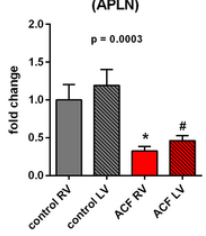

myocardial metabolism
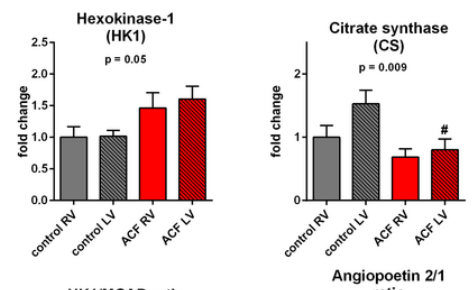

HK1/MCAD ratio

Angiopoetin 2/1

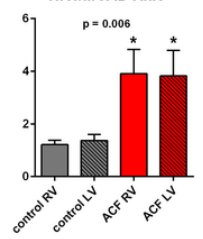

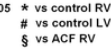

\section{Figure 3}

Gene mRNA expression analysis of cardiac markers of stress and metabolism. Gene mRNA expression analysis of selected genes that reflect a) myocardial stress, b) substrate metabolism and bioenergetics. Data are presented as means \pm SEM Changes normalized to control RV. $N=12$ in each group. $P$ value: ANOVA, and Tukey post-hoc tests. 
a

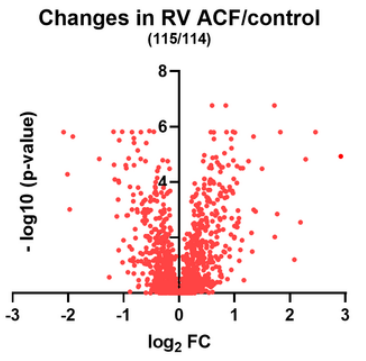

b

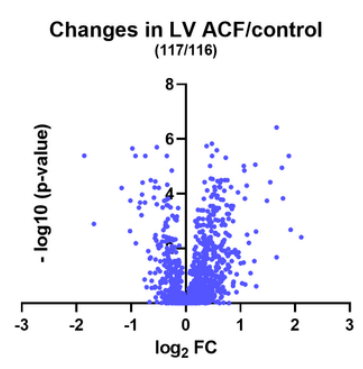

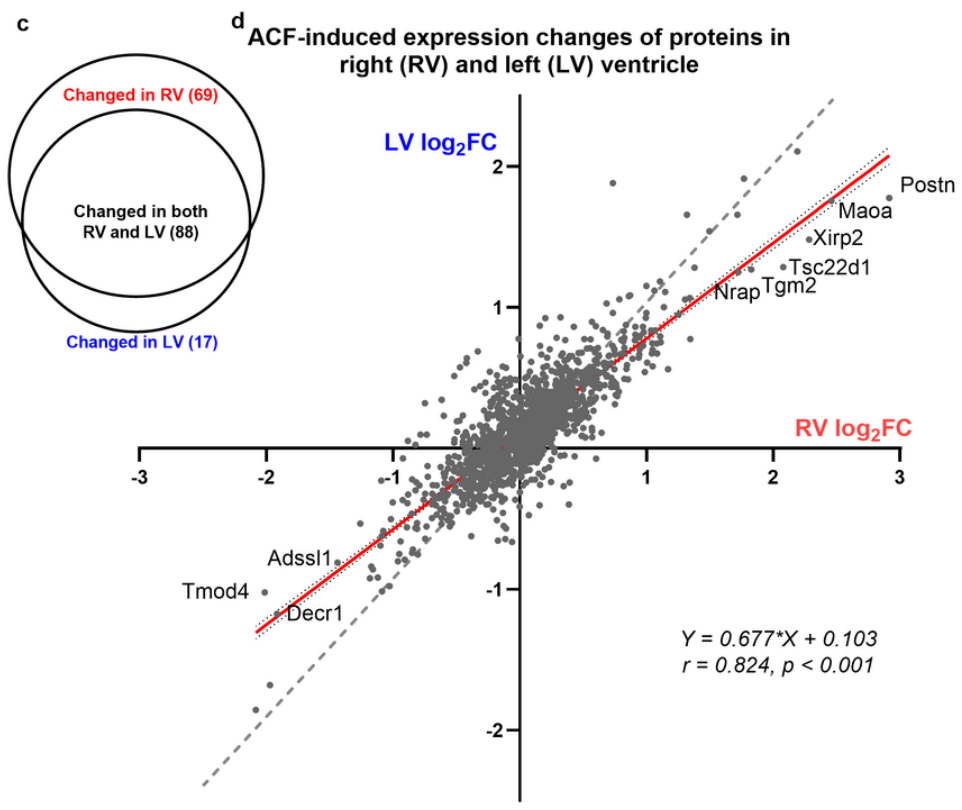

Figure 4

iTRAQ proteomic analysis of biventricular response to volume overload due to ACF. a, b) Vulcan plot of identified proteins in RV and LV. X axis represent log2 of fold change compared to controls, $Y$ axis - $\log 10$ of p-value. c) Venn diagrams of differentially regulated proteins in ACF compared to controls (significant difference with threshold > 1.5-fold). d) ACF-induced changes (log2 of fold-) in RV (X axis) vs LV (Y axis). Note departure of the regression line (with 95\% Cl, red) from identity line (dashed), towards RV. The proteins with relatively highest differential regulation in RV are labeled in red. For abbreviations, see text. 

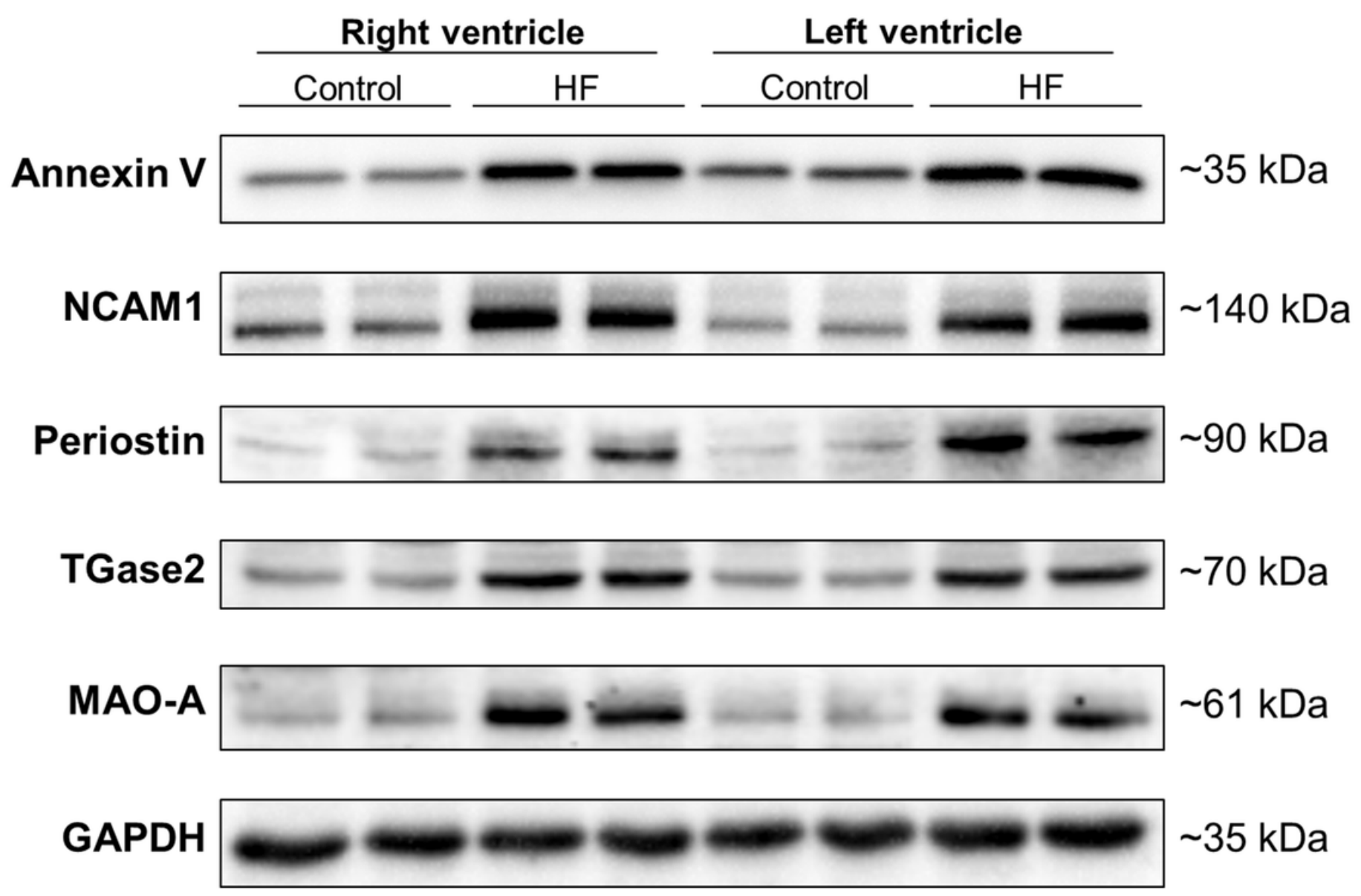

\section{Figure 5}

Confirmation of the differential expression of selected proteins using western blot analysis with specific antibodies. Pooled myocardial samples (40 $\mu \mathrm{g})$ were loaded and separated in duplicates. GAPDH was used as a loading control. NCAM-1 (Neural cell adhesion molecule 1), TGM2 (Tissue-type transglutaminase), MAO-A (Monoamine oxidase type A).

\section{Supplementary Files}

This is a list of supplementary files associated with this preprint. Click to download.

- SupplementarylnformationHavlenovaetal.pdf

- SupplementaryProteomicDataset.xlsx 